\section{Association of violence in schools' vicinity and smoking in schools' premises with tobacco use among Brazilian adolescents}

\author{
Associação entre violência no entorno da escola \\ e tabagismo no ambiente escolar e o uso de \\ tabaco por adolescentes brasileiros
}

\author{
Asociación de la violencia en las inmediaciones \\ de la escuela y fumar en dependencias escolares \\ con el consumo de tabaco entre adolescentes \\ brasileños
}

Alexandra Crispim Boing 1,2 Antonio Fernando Boing 1,2 S. V. Subramanian 2

doi: 10.1590/0102-311X00057919

\begin{abstract}
This study aims to quantify the overall importance of schools in explaining the individual variance of tobacco use and to test the association between characteristics of the school environment and its vicinity with the experimentation and current use of cigarettes. We analyzed data from 102,072 Brazilian adolescents interviewed in the 2015 National School Health Survey (PeNSE). Multilevel logistic regression models were performed to estimate the between-schools variance and to test the association between school-level variables and the use of tobacco. Violence in the vicinity of the school and presence of teachers or students smoking on school premises were the schoollevel characteristics. The analyses were adjusted by individual covariates and stratified by gender. Around 12.5\% of the individual variance in ever smoking was explained by between-school variation among girls (9.2\% among boys). The figures were even higher for current smoking (14.9\% girls; $12.2 \%$ boys) and current use of other tobacco products (27.7\% girls; $17.8 \%$ boys). In general, the use of tobacco was associated with the existence of violence in the vicinity of the schools and was higher among students whose schools reported that students and teachers (teachers only for use of other tobacco products among girls) smoke on school premises. Tobacco use on school premises and the safety of the neighborhood where the school is located are associated with some smoking behaviors among adolescents. Such findings reinforce the necessity to effectively consider interventions in the school environment and neighborhood to fight smoking among adolescents.
\end{abstract}

Tobacco; Smoking; Adolescent; Health Risk Behaviors; Multilevel Analysis

\author{
Correspondence \\ A. C. Boing \\ Departamento de Saúde Pública, Universidade Federal de Santa \\ Catarina. \\ Campus Universitário Trindade, Florianópolis, SC \\ 88040-900, Brasil. \\ alexandra.boing@ufsc.br \\ 1 Universidade Federal de Santa Catarina, Florianópolis, Brasil. \\ 2 Harvard T.H. Chan School of Public Health, Boston, U.S.A.
}




\section{Introduction}

Smoking continues to be the leading cause of preventable deaths worldwide 1 , accounting for more than 7 million deaths per year ${ }^{2}$. Although in recent decades, policies and actions have been successfully implemented to control smoking, resulting in the reduction of its prevalence in several countries, the absolute number of tobacco users in the world as a whole has not yet decreased 2 . In addition, there has been high increase of smoking prevalence in some low- and middle-income countries (LMICs), which currently account for around $80 \%$ of the world's 1.1 billion smokers 2 .

In these countries, the picture is especially worrying among young people. It is estimated that in more than 60 countries around the world, the prevalence of tobacco use among young people has increased or remained stationary between 1999 and 2016 3. Due to pro-smoking norms spread in the society and normative developmental processes characteristic of youth 4 , adolescents are a highly sensitive group to smoking initiation. People who begin consuming tobacco when adolescent are more likely to become regular smokers than those who begin smoking when adults 5 , and most of the current adult smokers began consuming tobacco products before they turned 186 . Thus, actions to prevent and reduce tobacco use among adolescents should be a public health priority, particularly among LMICs.

The design of effective public policies to stop early initiation of tobacco use among adolescents requires the expansion of knowledge about the factors associated with this behavior. Thus, studies have expanded their analysis by incorporating into their theoretical and analytical models not only individual or family characteristics, but also the characteristics of the neighborhood where the adolescents live and the school in which they study ${ }^{7}$.

At the individual and family level, a broad set of characteristics has been associated with smoking behavior among adolescents. Studies have reported a greater chance of smoking initiation among poorer adolescents 6 , whose parents or peer group smoke 8,9, victims of bullying 10, those with low academic performance 6 and those living a routine of family conflicts 11 . Regarding school environment, studies have reported that antismoking policy measures and curriculum lower the scholars' chances of smoking 7, while perceived smoking behavior on school grounds increases the odds of smoking 12. Nonetheless, little evidence exists on the impact of the school environment and vicinity on smoking among youth in LMICs 12,13. Furthermore, few studies explore multilevel models to perform these analyses and thus little is known about how much of the individual variance is attributable to between-schools differences and how much is attributable to between-individuals differences. Such information may allow researchers and policymakers to better understand the relative importance of these two different levels - individuals and schools - in terms of the smoking behavior among adolescents. Finally, the school context has a different social and behavioral impact depending on the adolescents' gender. The consequences may be greater for girls or for boys depending on the outcome and the schools' compositional characteristics, making it necessary to carry out stratified analyzes according to gender 14,15 .

The present study aims to quantify the overall importance of schools in explaining individual variance of tobacco use and to test the association between characteristics of the school environment and its vicinity with the experimentation and current use of cigarettes and other tobacco products among Brazilian adolescents.

\section{Methods}

\section{Participants}

This is a cross-sectional study with data from the 2015 National School Health Survey (PeNSE). PeNSE is a national survey with a focus on chronic diseases that has monitored schoolchildren's health in Brazil and has been held every three years between 2009 and 2015.

The study included 9th-grade elementary school students enrolled in public or private schools located in urban and rural areas throughout the country. In the state capitals, the primary sampling units (PSU) were the schools and the secondary sampling units (SSU) were the classes. In the non-state 
capitals, the PSU were groups of municipalities, the SSU were the schools and the classes were tertiary sampling units. Schools with less than 15 students in the 9th grade were excluded (which comprised approximately $3 \%$ of the registered students in Brazil), as well students from the night shift $(<3 \%$ of the students in the country). At each selected school, the 9th-grade classes were randomly selected with equal probabilities. All the students in the selected classes were invited to answer in electronic devices a self-administered, structured questionnaire. In addition, at each of the selected schools a questionnaire was applied to the principal (or the team in charge of the school) regarding the school environment, including information on school structure, size, spaces, equipment and policies. The data collection took place in 3,040 schools between April and September 2015. Detailed methodological information from the research was reported elsewhere 16.

\section{Measures}

We analyzed three different outcomes. The first was "ever smoking", defined as cigarette consumption at some point in life. The second was "current smoking", when the schoolchildren had smoked at least one day in the last month. Lastly, we analyzed the current use of other tobacco products, other than cigarettes, in the last 30 days. In this question, the following options were presented: straw or handrolled cigarettes, cigars, pipes, cigarillos, Indian or Bali cigarettes, hookah, snuff and chewing tobacco.

The school principal or the team in charge of the school provided information on the three explanatory variables used in this study: (i) presence of teachers smoking on school premises (no; yes); (ii) presence of students smoking on school premises (no; yes); and (iii) violence in the school's vicinity. The last variable was obtained through the following question: "In the last 12 months, how often was the locality of the school considered an area of risk in terms of violence (robbery, theft, assault, drugs, homicides, etc.)?" The analyzed categories were: never been considered a violent vicinity; yes, a few times in the last 12 months; yes, often.

We used, as individual covariates, age (11-13; 14-16; and 17-19 years old); race/skin color (white; black; Asian; brown/mixed; and indigenous); the mother's level of education (complete college; complete high school; complete elementary school; and incomplete elementary school); the type of school (private; public); and the parents' smoking behavior (none of them smoke; one of them smokes; and both of them smoke). We used multiple imputations to account for missing data observed in the mother's level of education. When performing the imputations, we used household goods and services (housemaid at least three times per week, internet connection, car, home telephone, mobile phone and number of bathrooms with a shower) as predictive variables.

\section{Data analysis}

We calculated different multilevel logistic regression models, considering the students as the first level of analysis and the schools as the second level. First, in order to estimate the proportion of the total observed individual variation in each one of the three outcomes that is attributable to between-school variation, we ran empty models. The variance partition coefficient (VPC) was calculated based on the latent response formulation, assuming an individual-level variance equal to $\pi^{2} / 317$.

Subsequently, we ran crude analyses, one for each outcome and each school variable. The other variables were included, successively conforming two multiple models. In the first model, all the school-level variables were included. In the second model, we adjusted by level-1 variables plus type of school, skin color/race, age, mother's level of education and parents' smoking behavior. The VPC, odds ratio (OR) and respective $95 \%$ confidence interval (95\% CI) were reported.

The data were analyzed in the statistical program Stata 14 (https://www.stata.com). The descriptive analyses incorporated the sampling design of the survey. The research was approved by the National Research Ethics Committee, which regulates human research in Brazil under the number: 1.006.467/201. 


\section{Results}

A total of 102,072 students were interviewed, $51.7 \%$ of them were girls. Nearly three-quarters of the students were between 14 and 16 years of age and 58.6\% were brown/mixed or black (Table 1). $28.1 \%$ of the girls and $25.4 \%$ of the boys reported that the mother or father smoked. Regarding school characteristics, $86.1 \%$ and $81.6 \%$ of the adolescents studied in a school whose principal reported that there are teachers or students smoking in their facilities, respectively. Lastly, more than two-thirds of adolescents studied at a school that reported violence in the neighborhood in the last 30 days.

Table 2 shows the prevalence of the outcomes according to individual and school characteristics. The prevalence of "ever smoking" and "current use" of tobacco (other than cigarettes) was significantly

\section{Table 1}

Sample distribution according to gender. Brazil, 2015.

\begin{tabular}{|c|c|c|c|}
\hline Characteristics & $\begin{array}{l}\text { Girls } \\
\text { n (\%) }\end{array}$ & $\begin{array}{l}\text { Boys } \\
\text { n (\%) }\end{array}$ & $\begin{array}{l}\text { Both } \\
\text { n (\%) }\end{array}$ \\
\hline \multicolumn{4}{|l|}{ Individual level } \\
\hline \multicolumn{4}{|l|}{ Age (years) } \\
\hline $11-13$ & $10,093(20.4)$ & $7,167(16.0)$ & $17,260(18.2)$ \\
\hline $14-16$ & $40,784(76.4)$ & $39,564(79.6)$ & $80,348(78.0)$ \\
\hline $17-19$ & $1,095(3.2)$ & $2,559(4.4)$ & $4,464(3.8)$ \\
\hline \multicolumn{4}{|l|}{ Race/Skin color } \\
\hline White & $16,779(35.0)$ & $16,996(37.4)$ & 33,775 (36.1) \\
\hline Black & $5,656(11.4)$ & $7,193(15.5)$ & $12,849(13.4)$ \\
\hline Asian & $2,717(4.6)$ & $1,863(3.6)$ & $4,580(4.1)$ \\
\hline Brown/Mixed & $25,779(46.0)$ & $21,156(39.9)$ & $46,935(43.0)$ \\
\hline Indigenous & $1,804(3.0)$ & $2,021(3.6)$ & $3,825(3.3)$ \\
\hline \multicolumn{4}{|l|}{ Mother's level of education } \\
\hline Complete college & $8,499(17.0)$ & $8,733(19.4)$ & $17,232(18.1)$ \\
\hline Complete high school & $12,009(30.2)$ & $11,350(31.5)$ & 23,359 (30.9) \\
\hline Complete elementary school & $6,366(16.9)$ & $5,933(17.4)$ & $12,299(17.1)$ \\
\hline Incomplete elementary school & $13,254(35.9)$ & $10,494(31.7)$ & $23,748(33.9)$ \\
\hline \multicolumn{4}{|l|}{ Type of school } \\
\hline Private & $10,753(20.4)$ & $10,165(20.6)$ & $20,918(20.5)$ \\
\hline Public & $42,029(79.6)$ & $39,125(79.4)$ & $81,154(79.5)$ \\
\hline \multicolumn{4}{|l|}{ Parents smoking behavior } \\
\hline None of them smoke & $38,347(71.9)$ & $36,751(74.6)$ & $75,098(73.2)$ \\
\hline One of them smokes & $11,160(23.2)$ & $9,402(21.4)$ & $20,562(22.3)$ \\
\hline Both of them smoke & $2,102(4.9)$ & $1,698(4.0)$ & $3,800(4.5)$ \\
\hline \multicolumn{4}{|l|}{ Contextual level (schools, $n=3,040$ ) } \\
\hline \multicolumn{4}{|c|}{ Presence of teachers smoking on school premises } \\
\hline No & $46,326(86.3)$ & $43,070(85.8)$ & $89.396(86.1)$ \\
\hline Yes & $6,382(13.7)$ & $6,153(14.2)$ & $12.535(13.9)$ \\
\hline \multicolumn{4}{|c|}{ Presence of students smoking on school premises } \\
\hline No & $41,820(81.7)$ & $38,899(81.2)$ & $80,719(81.6)$ \\
\hline Yes & $10,888(18.3)$ & $10,324(18.4)$ & $21,212(18.3)$ \\
\hline \multicolumn{4}{|l|}{ Violence in the vicinity of the school } \\
\hline No & $15,519(31.3)$ & $14,544(31.4)$ & $30,063(31.3)$ \\
\hline Yes, rarely & $23,897(46.4)$ & $22,269(46.1)$ & $46,166(46.2)$ \\
\hline Yes, often & $13,285(22.3)$ & $12,388(22.5)$ & $25,673(22.4)$ \\
\hline
\end{tabular}


Table 2

Prevalence of ever smoking, current smoking and current use of tobacco (except cigarettes) according to gender. Brazil, 2015.

\begin{tabular}{|c|c|c|c|c|c|c|}
\hline \multirow[t]{2}{*}{ Characteristics } & \multicolumn{3}{|c|}{ Girls [\% (95\%Cl)] } & \multicolumn{3}{|c|}{ Boys [\% (95\%Cl)] } \\
\hline & Ever smoking & Current smoking & $\begin{array}{l}\text { Current use of } \\
\text { tobacco (other } \\
\text { than cigarette) }\end{array}$ & Ever smoking & $\begin{array}{l}\text { Current } \\
\text { smoking }\end{array}$ & $\begin{array}{l}\text { Current use of } \\
\text { tobacco (other } \\
\text { than cigarette) }\end{array}$ \\
\hline All & $17.4(16.6-18.2)$ & $5.4(4.9-5.8)$ & $5.6(5.2-6.0)$ & $19.4(18.7-20.2)$ & $5.8(5.4-6.3)$ & $6.5(6.1-7.0)$ \\
\hline \multicolumn{7}{|l|}{ Individual level } \\
\hline \multicolumn{7}{|l|}{ Age (years) } \\
\hline $11-13$ & $10.4(9.2-11.6)$ & $2.9(2.2-3.8)$ & $4.6(3.8-5.6)$ & $11.5(10.1-13.1)$ & $2.5(1.7-3.5)$ & $4.9(3.9-6.1)$ \\
\hline $14-16$ & $18.9(18.0-19.8)$ & $5.8(5.3-6.3)$ & $5.9(5.4-6.4)$ & $20.2(19.4-21.2)$ & $6.1(5.6-6.7)$ & $6.8(6.3-7.3)$ \\
\hline $17-19$ & $27.0(24.1-30.1)$ & $10.8(8.7-13.2)$ & $5.1(3.7-7.1)$ & $33.4(30.7-36.2)$ & $13.4(11.3-15.8)$ & $8.4(7.0-10.1)$ \\
\hline \multicolumn{7}{|l|}{ Race/Skin color } \\
\hline White & $16.8(15.6-18.0)$ & $4.9(4.4-5.6)$ & $6.1(5.3-6.9)$ & $18.2(17.1-19.4)$ & $5.4(4.8-6.1)$ & $6.6(6.0-7.4)$ \\
\hline Black & $18.0(16.3-19.8)$ & $6.4(5.3-7.7)$ & $5.9(4.8-5.2)$ & $22.8(21.0-24.7)$ & $7.5(6.2-9.1)$ & $7.6(6.6-8.8)$ \\
\hline Asian & $17.6(15.1-20.3)$ & $5.6(4.0-7.9)$ & $5.2(4.0-6.8)$ & $18.0(15.4-20.8)$ & $3.8(2.7-5.2)$ & $6.2(4.6-8.3)$ \\
\hline Brown/Mixed & $17.6(16.5-18.6)$ & $5.3(4.7-5.9)$ & $5.2(4.6-6.0)$ & $19.2(18.1-20.2)$ & $5.7(5.1-6.4)$ & $6.1(5.5-6.8)$ \\
\hline Indigenous & $19.2(16.2-22.4)$ & $6.4(4.5-9.2)$ & $4.2(3.0-5.9)$ & $22.5(19.2-26.1)$ & $6.6(4.8-8.9)$ & $6.4(4.6-9.0)$ \\
\hline \multicolumn{7}{|l|}{ Mothers education } \\
\hline Complete college & $13.2(11.6-15.0)$ & $4.6(3.8-5.7)$ & $5.0(4.0-6.1)$ & $17.4(15.9-19.0)$ & $5.1(4.2-6.2)$ & $8.1(7.0-9.4)$ \\
\hline Complete high school & $17.2(16.0-18.6)$ & $5.3(4.5-6.3)$ & $6.9(5.9-8.1)$ & $18.4(17.1-19.8)$ & $5.6(4.9-6.4)$ & $6.2(5.4-7.2)$ \\
\hline $\begin{array}{l}\text { Complete elementary } \\
\text { school }\end{array}$ & $18.2(16.5-20.1)$ & $4.7(3.8-5.6)$ & $5.9(4.8-7.3)$ & $20.3(18.5-22.1)$ & $5.4(4.4-6.6)$ & $6.8(5.7-8.1)$ \\
\hline $\begin{array}{l}\text { Incomplete } \\
\text { elementary school }\end{array}$ & $19.4(18.1-20.7)$ & $5.5(4.9-6.3)$ & $4.7(4.0-5.4)$ & $22.0(20.6-23.4)$ & $6.8(6.0-7.8)$ & $6.4(5.5-7.4)$ \\
\hline \multicolumn{7}{|l|}{ Type of school } \\
\hline Private & $11.6(10.2-13.1)$ & $3.4(2.6-4.4)$ & $4.0(3.2-4.8)$ & $13.7(12.4-15.1)$ & $3.8(3.1-4.8)$ & $6.4(5.5-7.6)$ \\
\hline Public & $18.4(17.5-19.3)$ & $5.7(5.2-6.2)$ & $5.9(5.4-6.4)$ & $20.4(19.6-21.3)$ & $6.2(6.6-6.8)$ & $6.5(6.1-7.1)$ \\
\hline \multicolumn{7}{|l|}{ Parents smoke } \\
\hline No & $14.0(13.3-14.8)$ & $3.9(3.5-4.4)$ & $4.4(3.9-4.9)$ & $16.6(15.9-17.3)$ & $4.6(4.2-5.0)$ & $5.1(4.7-5.6)$ \\
\hline Yes, one of them & $24.5(23.0-26.1)$ & $8.0(7.0-9.1)$ & $7.6(6.6-8.7)$ & $25.8(24.1-27.6)$ & $8.0(7.0-9.0)$ & $9.1(8.1-10.2)$ \\
\hline Yes, both of them & $30.4(27.1-34.0)$ & $11.5(9.4-14.0)$ & $12.7(10.4-15.4)$ & $31.4(27.4-36.7)$ & $11.6(8.6-15.6)$ & $12.5(9.7-16.2)$ \\
\hline \multicolumn{7}{|l|}{$\begin{array}{l}\text { Contextual level } \\
\text { (schools, } n=3,040 \text { ) }\end{array}$} \\
\hline \multicolumn{7}{|l|}{$\begin{array}{l}\text { Presence of teachers } \\
\text { smoking on school } \\
\text { premises }\end{array}$} \\
\hline No & $17.1(16.3-18.0)$ & $5.2(4.7-5.8)$ & $5.4(4.9-6.0)$ & $19.0(18.2-19.8)$ & $5.8(5.3-6.3)$ & $6.4(5.9-6.8)$ \\
\hline Yes & $19.0(17.4-20.7)$ & $6.3(5.4-7.4)$ & $6.6(5.6-7.8)$ & $21.9(19.6-24.4)$ & $6.2(4.7-8.2)$ & $7.7(6.3-9.4)$ \\
\hline \multicolumn{7}{|l|}{$\begin{array}{l}\text { Presence of students } \\
\text { smoking on school } \\
\text { premises }\end{array}$} \\
\hline No & $16.5(15.7-17.3)$ & $5.0(4.5-5.6)$ & $5.3(4.8-5.8)$ & $18.6(17.7-19.4)$ & $5.6(5.1-6.2)$ & $6.4(5.9-6.9)$ \\
\hline Yes & $21.5(19.3-23.9)$ & $6.9(5.8-8.2)$ & $6.9(5.8-8.1)$ & $23.3(21.8-24.9)$ & $6.7(5.9-7.5)$ & $7.4(6.5-8.4)$ \\
\hline \multicolumn{7}{|l|}{$\begin{array}{l}\text { Violence in the vicinity of } \\
\text { the school }\end{array}$} \\
\hline No & $15.2(14.0-16.4)$ & $4.2(3.6-4.8)$ & $4.2(3.6-5.0)$ & $18.6(17.4-20.0)$ & $5.0(4.3-5.8)$ & $5.9(5.3-6.7)$ \\
\hline Yes, rarely & $17.4(16.1-18.7)$ & $5.9(5.1-6.7)$ & $6.2(5.4-7.0)$ & $19.2(18.1-20.4)$ & $6.1(5.3-7.0)$ & $6.6(6.0-7.4)$ \\
\hline Yes, often & $20.6(19.0-22.2)$ & $6.0(5.0-7.1)$ & $6.2(5.5-7.2)$ & $20.9(19.4-22.4)$ & $6.4(5.7-7.3)$ & $7.2(6.4-8.0)$ \\
\hline
\end{tabular}


higher among boys. The proportion of boys and girls currently smoking was similar. In all outcomes, the older adolescents and the students whose parents were smokers reported a higher prevalence of cigarette and other tobacco use, with a clear dose-response effect. The prevalence of cigarette smoking and use of other tobacco products were higher in schools reporting a higher frequency of violence in the vicinity.

We found high between-school variance when analyzing both current and previous consumption of tobacco, particularly among girls (Table 3). For "ever smoking", the VPC values were close to $12.5 \%$ among girls and $9.2 \%$ among boys in the empty models. When "current use" was analyzed, the figures were higher than $14.9 \%$ among girls and about $12.2 \%$ among boys. The highest between-school variance was observed in the current use of tobacco (other than cigarettes): $27.7 \%$ among girls and $17.8 \%$ among boys. When adjusted by individual variables, the variance did not decrease expressively.

The chance of ever having smoked was 32\% higher among girls and $8 \%$ higher among boys whose schools were located in a place with frequent occurrences of violent episodes, even after full adjustment of the model (Tables 4 and 5). Among these same groups, the probability of current smoking was $31 \%$ and $13 \%$ higher, respectively, when compared to schools with no record of violence in the neighborhood.

The probability of the three outcomes was highest among boys and girls whose principal reported being aware of students smoking in their facilities. In adjusted models, the highest OR was 1.37 for current smoking among girls and the lowest was 1.19 for ever having smoked among boys. On the other hand, the existence of teachers smoking on school premises was associated only with current use of tobacco (other than cigarettes) among girls (OR = 1.33; 95\%CI: 1.09-1.63). Despite the associations observed, the proportion of between-schools variance explained by these school-level variables was low, ranging from $1.9 \%$ to $6.6 \%$ (Table 3 ).

\section{Discussion}

The present study has found that (i) a significant proportion of the individual variance in tobacco use is explained by between-school variation; (ii) in general, the use of tobacco is associated with the existence of violence in the vicinity of schools and is higher among students whose schools report that students and teachers (teachers only for use of other tobacco products among girls) smoke on the school premises; (iii) there is higher prevalence of tobacco use among boys, older adolescents and those whose parents are smokers and whose mothers did not complete elementary school (only for "ever" and "current" cigarette smoking).

Table 3

Between-schools variance in empty and adjusted models and proportion of between-schools variance explained by school-level variables. Brazil, 2015.

\begin{tabular}{|c|c|c|c|}
\hline Characteristics & Ever smoking & $\begin{array}{l}\text { Current } \\
\text { smoking }\end{array}$ & $\begin{array}{l}\text { Current use of tobacco } \\
\text { (other than cigarette) }\end{array}$ \\
\hline \multicolumn{4}{|l|}{ Girls } \\
\hline Between-schools variance in empty model (VPC) & $0.469(12.5 \%)$ & $0.574(14.9 \%)$ & $1.255(27.7 \%)$ \\
\hline Between-schools variance in model adjusted * by individual variables & 0.366 & 0.454 & 1.194 \\
\hline$\%$ of between-schools variance explained by school-level variables ** & 6.6 & 5.4 & 1.9 \\
\hline \multicolumn{4}{|l|}{ Boys } \\
\hline Between-schools variance in empty model (VPC) & $0.334(9.2 \%)$ & $0.456(12.2)$ & $0.711(17.8 \%)$ \\
\hline Between-schools variance in model adjusted * by individual variables & 0.256 & 0.339 & 0.697 \\
\hline$\%$ of between-schools variance explained by school-level variables ** & 5.7 & 6.1 & 4.2 \\
\hline
\end{tabular}

VPC: variance partition coefficient.

* Adjusted by type of school, skin color/race, age, mother's level of education, and parents smoking behavior;

** We used the following school-level variables: presence of teachers smoking on school premises, presence of students smoking in the school,

existence of violence in the vicinity of the school. 
Table 4

Association between use of tobacco and school environment in girls. Brazil, 2015.

\begin{tabular}{|c|c|c|c|}
\hline Variables & $\begin{array}{l}\text { Crude model } \\
\text { OR }(95 \% \mathrm{CI})\end{array}$ & $\begin{array}{c}\text { Model } 1 \\
\text { OR }(95 \% \mathrm{CI})\end{array}$ & $\begin{array}{c}\text { Model } 2 \\
\text { OR }(95 \% \mathrm{CI})\end{array}$ \\
\hline \multicolumn{4}{|l|}{ Ever smoking } \\
\hline \multicolumn{4}{|c|}{ Presence of teachers smoking on school premises } \\
\hline No & 1.00 & 1.00 & 1.00 \\
\hline Yes & $1.14(1.02-1.27)$ & $1.02(0.92-1.14)$ & $0.99(0.88-1.10)$ \\
\hline \multicolumn{4}{|c|}{ Presence of students smoking on school premises } \\
\hline No & 1.00 & 1.00 & 1.00 \\
\hline Yes & $1.44(1.32-1.56)$ & $1.35(1.24-1.48)$ & $1.25(1.14-1.36)$ \\
\hline \multicolumn{4}{|c|}{ Violence in the vicinity of the school } \\
\hline No & 1.00 & 1.00 & 1.00 \\
\hline Yes, rarely & $1.20(1.11-1.31)$ & $1.18(1.09-1.28)$ & $1.20(1.11-1.31)$ \\
\hline Yes, often & $1.50(1.37-1.66)$ & $1.42(1.29-1.56)$ & $1.32(1.20-1.45)$ \\
\hline \multicolumn{4}{|c|}{ Current smoking } \\
\hline \multicolumn{4}{|c|}{ Presence of teachers smoking on school premises } \\
\hline No & 1.00 & 1.00 & 1.00 \\
\hline Yes & $1.23(1.06-1.43)$ & $1.07(0.92-1.25)$ & $1.04(0.89-1.22)$ \\
\hline \multicolumn{4}{|c|}{ Presence of students smoking on school premises } \\
\hline No & 1.00 & 1.00 & 1.00 \\
\hline Yes & $1.54(1.37-1.74)$ & $1.45(1.28-1.64)$ & $1.37(1.20-1.56)$ \\
\hline \multicolumn{4}{|c|}{ Violence in the vicinity of the school } \\
\hline No & 1.00 & 1.00 & 1.00 \\
\hline Yes, rarely & $1.29(1.14-1.46)$ & $1.26(1.11-1.42)$ & $1.29(1.13-1.46)$ \\
\hline Yes, often & $1.49(1.30-1.72)$ & $1.39(1.20-1.60)$ & $1.31(1.13-1.52)$ \\
\hline \multicolumn{4}{|c|}{ Current use of tobacco (other than cigarette) } \\
\hline \multicolumn{4}{|c|}{ Presence of teachers smoking on school premises } \\
\hline No & 1.00 & 1.00 & 1.00 \\
\hline Yes & $1.47(1.22-1.78)$ & $1.36(1.12-1.66)$ & $1.33(1.09-1.63)$ \\
\hline \multicolumn{4}{|c|}{ Presence of students smoking on school premises } \\
\hline No & 1.00 & 1.00 & 1.00 \\
\hline Yes & $1.39(1.19-1.62)$ & $1.27(1.07-1.50)$ & $1.24(1.04-1.47)$ \\
\hline \multicolumn{4}{|c|}{ Violence in the vicinity of the school } \\
\hline No & 1.00 & 1.00 & 1.00 \\
\hline Yes, rarely & $1.35(1.15-1.57)$ & $1.33(1.14-1.55)$ & $1.32(1.12-1.54)$ \\
\hline Yes, often & $1.27(1.06-1.52)$ & $1.20(1.00-1.44)$ & $1.19(0.99-1.44)$ \\
\hline
\end{tabular}

Model 1: adjusted by all school-level variables; Model 2: adjusted by school-level variables plus type of school, skin color/race, age, mother's level of education, and parents smoking behavior.

The prevalence of ever smoking, current cigarette smoking and current use of tobacco (other than cigarettes) among Brazilian adolescents were below the world median. The Global Youth Tobacco Survey analyzed surveys from 43 countries and found that the median prevalence of ever smoking was 33\%, ranging from 79.8\% (Northern Mariana Islands) to 3.4\% (Tamil Nadu, India). The median world prevalence of current cigarette smoking was $13.9 \%$ and the use of other tobacco products was reported by $8.8 \%$ of the youths 18 . The variation of the prevalence among countries occurs due to a different level of exposure to smoking determinants, such as cultural and religious aspects, access to tobacco, existence of effective policies for tobacco control, school environment, socioeconomic conditions and the tobacco industry's influence.

The individual-level findings of the present study corroborate the results of previous investigations. We also observed the relevant influence of parental smoking on adolescent smoking. 
Table 5

Association between use of tobacco and school environment in boys. Brazil, 2015.

\begin{tabular}{|c|c|c|c|}
\hline Variables & $\begin{array}{l}\text { Crude model } \\
\text { OR }(95 \% \mathrm{Cl})\end{array}$ & $\begin{array}{c}\text { Model } 1 \\
\text { OR }(95 \% \mathrm{Cl})\end{array}$ & $\begin{array}{c}\text { Model } 2 \\
\text { OR }(95 \% \mathrm{Cl})\end{array}$ \\
\hline \multicolumn{4}{|l|}{ Ever smoking } \\
\hline \multicolumn{4}{|c|}{ Presence of teachers smoking on school premises } \\
\hline No & 1.00 & 1.00 & 1.00 \\
\hline Yes & $1.12(1.02-1.24)$ & $1.02(0.93-1.13)$ & $1.02(0.92-1.12)$ \\
\hline \multicolumn{4}{|c|}{ Presence of students smoking on school premises } \\
\hline No & 1.00 & 1.00 & 1.00 \\
\hline Yes & $1.36(1.26-1.47)$ & $1.32(1.22-1.43)$ & $1.19(1.10-1.29)$ \\
\hline \multicolumn{4}{|c|}{ Violence in the vicinity of the school } \\
\hline No & 1.00 & 1.00 & 1.00 \\
\hline Yes, rarely & $1.02(0.95-1.10)$ & $1.01(0.94-1.09)$ & $1.02(0.94-1.10)$ \\
\hline Yes, often & $1.22(1.12-1.33)$ & $1.16(1.06-1.26)$ & $1.08(0.99-1.18)$ \\
\hline \multicolumn{4}{|c|}{ Current smoking } \\
\hline \multicolumn{4}{|c|}{ Presence of teachers smoking on school premises } \\
\hline No & 1.00 & 1.00 & 1.00 \\
\hline Yes & $1.06(0.92-1.22)$ & $0.94(0.81-1.09)$ & $0.92(0.79-1.07)$ \\
\hline \multicolumn{4}{|c|}{ Presence of students smoking on school premises } \\
\hline No & 1.00 & 1.00 & 1.00 \\
\hline Yes & $1.47(1.31-1.64)$ & $1.44(1.28-1.62)$ & $1.27(1.13-1.44)$ \\
\hline \multicolumn{4}{|c|}{ Violence in the vicinity of the school } \\
\hline No & 1.00 & 1.00 & 1.00 \\
\hline Yes, rarely & $1.06(0.94-1.18)$ & $1.03(0.92-1.15)$ & $1.09(0.97-1.22)$ \\
\hline Yes, often & $1.26(1.10-1.43)$ & $1.17(1.02-1.33)$ & $1.13(0.99-1.29)$ \\
\hline \multicolumn{4}{|c|}{ Current use of tobacco (other than cigarette) } \\
\hline \multicolumn{4}{|c|}{ Presence of teachers smoking on school premises } \\
\hline No & 1.00 & 1.00 & 1.00 \\
\hline Yes & $1.29(1.10-1.50)$ & $1.17(1.00-1.37)$ & $1.16(0.98-1.38)$ \\
\hline \multicolumn{4}{|c|}{ Presence of students smoking on school premises } \\
\hline No & 1.00 & 1.00 & 1.00 \\
\hline Yes & $1.43(1.26-1.62)$ & $1.36(1.19-1.55)$ & $1.31(1.14-1.50)$ \\
\hline \multicolumn{4}{|c|}{ Violence in the vicinity of the school } \\
\hline No & 1.00 & 1.00 & 1.00 \\
\hline Yes, rarely & $1.01(0.89-1.15)$ & $0.99(0.88-1.13)$ & $0.98(0.86-1.12)$ \\
\hline Yes, often & $1.12(0.97-1.29)$ & $1.05(0.91-1.22)$ & $1.00(0.86-1.17)$ \\
\hline
\end{tabular}

Model 1: adjusted by all school-level variables; Model 2: adjusted by school-level variables plus type of school, skin color/race, age, mother's level of education, and parents smoking behavior.

A multigeneration study carried out by Mays et al. 19 found that adolescents whose parents were smokers and nicotine dependent were more likely to be early regular smokers and early experimenters when compared to adolescents with non-nicotine-dependent parents. The study reported that adolescents with nicotine-dependent parents are susceptible to more intense smoking patterns and that risk increases with longer duration of exposure 19. Many other surveys and systematic reviews have corroborated this finding 20,21,22. According to these studies, that happens due to multiple factors, but mainly by observation and imitation of parental behavior, the internalization of parental smoking norms, parental socialization of the adolescent, the availability of cigarettes at home and genetic predisposition 23,24. 
Parental smoking may also partly explain the association observed in many studies between family socioeconomic status and adolescent smoking ${ }^{25}$. In the present study we observed that ever and current cigarette smoking prevalence were higher among adolescents whose mother did not complete elementary school, whereas the use of other types of tobacco was higher among children of mothers with higher educational level. Other studies have reported similar results and such association may be related to better life opportunities for offspring in high socioeconomic status families, high quality of health education, lower availability of tobacco 26 , higher benefit from tobacco control policies 27 and the availability of other resources to cope with stressful situations. The higher cost of some tobacco products (excluding cigarettes), like hookah, may explain the positive association observed in this study between high parental socioeconomic status and the use of other tobacco products. Nonetheless, some studies have not found among adolescents the same negative association observed among adults between socioeconomic status and smoking 28 .

This study found that the school context explains an important part of the individual variation in tobacco use. Adolescence is characterized by higher peer influences, low levels of future orientation and low risk perception, increasing the risk of engaging in unhealthy behaviors 29 . In this scenario, the school environment has profound impact on adolescents' health behaviors. The school's ethos - a set of values, practices, organization and attitudes - performs a pivotal role in shaping the adolescent's health behaviors, which will affect his whole life 30 . In the present study the contextual impact was higher among girls. Previous studies reported that the associations between poorer school climates and health are greater for girls, as highlighted by Saab \& Klinger 31. Disorderly and rowdy lessons, for instance, contributed to feelings of stress among girls, but not among boys. Moreover, girls were reported to be more affected at school by lack of control, affecting self-worth ${ }^{32}$. Nonetheless, the effects of schools' context on gender differences in health are far from being settled and more studies are necessary.

We observed that some tobacco use outcomes are associated with the existence of violence in the vicinity of the school. Recent evidence has identified that witnessing violence is associated with health risk behaviors 33. A study conducted with Boston (United States) students identified that adolescents who witnessed violent death were more likely to smoke (20\% higher among boys and $9 \%$ higher among girls) 34 . Studying in a violent neighborhood may increase students' chances of witnessing or experiencing violence, having negative and stressful feelings and spending less time in public spaces. Fear of crime has a negative effect on well-being and has direct physiological and behavioral consequences for health 35 . Coping with such a situation may be challenging for many adolescents and under stressful conditions engagement in negative behaviors, like smoking, can be an answer for them 36,37 . Viner et al. 29 conducted a country-level ecological analysis on the health of young people and stated that safe schools are crucial to young people's health both in rich and low- and middleincome countries.

However, certainly not all cases of violence result in adverse health events, as this may depend on the availability of resources for coping. For example, social support is an important tool for adolescents and serves to help them cope with stress, allowing them to avoid risky behaviors 38 . Thus, strategies to address smoking among adolescents should provide safe school neighborhoods and promote connectivity and social support. The occurrence of smoking on school property, whether by students or teachers, speaks to the necessity of a school tobacco-free environment. The association between perceived smoking on school premises and adolescent smoking has been described in other countries $39,40,41$ and demands deeper discussion on how to protect adolescents from exposure to tobacco inside the schools. Seeing peers and/or teachers smoking makes this behavior usual or socially acceptable for adolescents, mainly when it happens in school. It also increases the visibility of negative role models to youth and presents opportunities for them to smoke 42 .

In Brazil the schools are considered smoke free, yet around one out of six adolescents studies in a school where the principal is aware that teachers/students are smoking on the premises. Enforcing school smoking-ban policies seems to be necessary in the country, since the significant effect of enforced bans in schools on adolescent smoking is well known 43.

This study has limitations. The presence of teachers and students smoking on school premises was not reported by the adolescents, but by the school's principal. The most important effect on the youth smoking behavior is what they see, which is not necessarily the same as reported by the 
administration staff. Furthermore, people in charge of the schools may give a more socially accepted answer when asked if they are aware of students and teachers smoking in the school. Regarding the information on violence in the school's vicinity, it's worth to note that the variable used in this study in subjective. It is based on just one person's opinion; the same frequency of a violent problem may be considered "rare" for one principal and "frequent" for another one. The students' information were obtained by self-applied interviews and under-reports or misinformation can occur. However, the use of electronic devices to gather the information, with no need for the student to tell anyone what his or her answers were, may have helped to stimulate more reliable outputs. We used only the mother's level of education as socioeconomic variable, so residual confounding may have occurred. Due to operational limitations of the software, we did not consider the complex sampling design in the multilevel models. It is unlikely that this procedure has had significant effect on the estimated ORs, but may have affected the standard errors and 95\%CI. Finally, this was a cross-section study, so causal relationships cannot be inferred.

The results of the present study reinforce the importance of the school context on smoking behaviors among adolescents. The presence of peers and teachers smoking in school's premises and violence in the vicinity of the school were associated with some of the analyzed outcomes, but did not explain much of the between-schools variance. Actions that increase the quantity of smoke-free schools and that promote healthier and safer environments are necessary. New studies should focus on new context variables that help to explain the between-schools variance.

\section{Contributors}

A. C. Boing conceived of the study, analyzed the data and drafted the manuscript. A. F. Boing analyzed the data, participated in the interpretation of the results and helped to draft the manuscript. S. V. Subramanian participated in the design of the study and helped to draft the manuscript.

\section{Additional informations}

ORCID: Alexandra Crispim Boing (0000-00017792-4824); Antonio Fernando Boing (0000-00019331-1550); S. V. Subramanian (0000-0003-23654165).

\section{References}

1. GBD 2015 Risk Factors Collaborators. Global, regional, and national comparative risk assessment of 79 behavioural, environmental and occupational, and metabolic risks or clusters of risks, 1990-2015: a systematic analysis for the Global Burden of Disease Study 2015. Lancet 2016; 388:1659-724.

2. World Health Organization. WHO report on the global tobacco epidemic 2017: monitoring tobacco use and prevention policies. Geneva: World Health Organization; 2017.

3. Drope J, Schluger NW, editors. The tobacco atlas. $6^{\text {th }}$ Ed. Atlanta: American Cancer Society/ Vital Strategies; 2018.

4. Lydon DM, Wilson SJ, Child A, Geier CF. Adolescent brain maturation and smoking: what we know and where we're headed. Neurosci Biobehav Rev 2014; 45:323-42.

5. Myers MG, Brown SA. Smoking and health in substance abusing adolescents: a 2 year followup. Pediatrics 1994; 93:561-6.

6. National Center for Chronic Disease Prevention and Health Promotion, Office on Smoking and Health. Preventing tobacco use among youth and young adults: a report of the surgeon general. Atlanta: Centers for Disease Control and Prevention; 2012.

7. Kim HH, Chun J. Analyzing multilevel factors underlying adolescent smoking behaviors: the roles of friendship network, family relations, and school environment. J Sch Health 2018; 88:434-43. 
8. Gilman SE, Rende R, Boergers J, Abrams DB, Buka SL, Clark MA, et al. Parental smoking and adolescent smoking initiation: an intergenerational perspective on tobacco control. Pediatrics 2009; 123:e274-81.

9. Mahabee-Gittens EM, Xiao Y, Gordon JS, Khoury JC. The dynamic role of parental influences in preventing adolescent smoking initiation. Addict Behav 2013; 38:1905-11.

10. Weiss JW, Mouttapa M, Cen S, Johnson CA, Unger J. Longitudinal effects of hospitality, depression, and bullying on adolescent smoking initiation. J Adolesc Health 2011; 48:591-6.

11. Rajesh V, Diamond PM, Spitz MR, Wilkinson AV. Smoking initiation among Mexican heritage youth and the roles of family cohesion and conflict. J Adolesc Health 2015; 57:24-30.

12. Nikaj S, Chaloupka F. School personnel smoking, school-level policies, and adolescent smoking in low- and middle- income countries. Tob Control 2016; 25:664-70.

13. Escario JJ, Wilkinson AV. Visibility of smoking among school-teachers in Spain and associations with student smoking: a cross-sectional study. BMJ Open 2018; 8:e018736.

14. Simmons RG, Blyth DA. Moving into adolescence: the impact of pubertal change and school context. New York: Aldine de Gruyter; 1987.

15. Botticello AL. A multilevel analysis of gender differences in psychological distress over time. J Res Adolesc 2009; 19:217-47.

16. Instituto Brasileiro de Geografia e Estatística. Pesquisa Nacional de Saúde do Escolar 2015. Rio de Janeiro: Instituto Brasileiro de Geografia e Estatística; 2016.

17. Merlo J, Chaix B, Yang M, Lynch J, Råstam L. A brief conceptual tutorial of multilevel analysis in social epidemiology: linking the statistical concept of clustering to the idea of contextual phenomenon. J Epidemiol Community Health 2005; 59:443-9.

18. Global Youth Tabacco Survey Collaborative Group. Tobacco use among youth: a cross country comparison. Tob Control 2002; 11:252-70.

19. Mays D, Gilman SE, Rende R, Luta G, Tercyak KP, Niaura RS. Parental smoking exposure and adolescent smoking trajectories. Pediatrics 2014; 133:983-91.

20. Scalici F, Schulz PJ. Parents' and peers' normative influence on adolescents' smoking: results from a Swiss-Italian sample of middle schools students. Subst Abuse Treat Prev Policy 2017; 12:5.

21. Wellman RJ, Dugas EN, Dutczak $H$, O'Loughlin EK, Datta GD, Lauzon B, et al. Predictors of the onset of cigarette smoking: a systematic review of longitudinal populationbased studies in youth. Am J Prev Med 2016; 51:767-78.

22. Vuolo M, Staff J. Parent and child cigarette use: a longitudinal, multigenerational study. Pediatrics 2013; 132:e568-77.
23. Kandel DB, Griesler PC, Hu MC. Intergenerational patterns of smoking and nicotine dependence among US adolescents. Am J Public Health 2015; 105:e63-72.

24. Lakon CM, Wang C, Butts CT, Jose R, Timberlake DS, Hipp JR. A dynamic model of adolescent friendship networks, parental influences, and smoking. J Youth Adolesc 2015; 44:176786.

25. Pedersen W, Soest TV. How is low parental socioeconomic status associated with future smoking and nicotine dependence in offspring? A population-based longitudinal 13-year follow-up. Scand J Public Health 2017; 45:16-24.

26. Soteriades ES, DiFranza JR. Parent's socioeconomic status, adolescents' disposable income, and adolescents' smoking status in Massachusetts. Am J Public Health 2003; 93:1155-60.

27. Kuipers MAG, Monshouwer K, van Laar M, Kunst AE. Tobacco control and socioeconomic inequalities in adolescent smoking in Europe. Am J Prev Med 2015; 49:e64-72.

28. Hanson MD, Chen E. Socioeconomic status and health behaviors in adolescence: a review of the literature. J Behav Med 2007; 30:263-85.

29. Viner RM, Ozer EM, Denny S, Marmot M, Resnick M, Fatusi A, et al. Adolescence and the social determinants of health. Lancet 2012; 379:1641-52.

30. Bonell C, Jamal F, Harden A, Wells H, Parry W, Fletcher A, et al. Systematic review of the effects of schools and school environment interventions on health: evidence mapping and synthesis. Southampton: NIHR Journals Library; 2013.

31. Saab H, Klinger D. School differences in adolescent health and wellbeing: findings from the Canadian health behaviour in school-aged children study. Soc Sci Med 2010; 70:850-8.

32. Gådin KG, Hammarström A. School-related health: a cross-sectional study among young boys and girls. Int J Health Serv 2000; 30:797820.

33. Dowdell EB. Urban seventh grade students: a report of health risk behaviors and exposure to violence. J Sch Nurs 2012; 28:130-7.

34. Pabayo R, Molnar BE, Kawachi I. Witnessing a violent death and smoking, alcohol consumption, and marijuana use among adolescents. J Urban Health 2014; 91:335-54.

35. Stafford M, Chandola T, Marmot M. Association between fear of crime and mental health and physical functioning. Am J Public Health 2007; 97:2076-81.

36. Altman CE, Gorman BK, Chávez S. Exposure to violence, coping strategies, and diagnosed mental health problems among adults in a migrant-sending community in Central Mexico. Popul Res Policy Rev 2018; 37:229-60.

37. Berenson AB, Wiemann CM, McCombs S. Exposure to violence and associated health-risk behaviors among adolescent girls. Arch Pediatr Adolesc Med 2001; 155:1238-42. 
38. Peirce RS, Frone MR, Russell M, Cooper ML, Mudar P. A longitudinal model of social contact, social support, depression, and alcohol use. Health Psychol 2000; 19:28-38.

39. Sabiston CM, Lovato CY, Ahmed R, Pullman AW, Hadd V, Campbell HS, et al. School smoking policy characteristics and individual perceptions of the school tobacco context: are they linked to students' smoking status? J Youth Adolesc 2009; 38:1374-87.

40. Huang C, Koplan J, Yu S, Li C, Guo C, Liu J, et al. Smoking experimentation among elementary school students in China: influences from peers, families, and the school environment. PLoS One 2013; 8:e73048.
41. Roohafza H, Heidari K, Omidi R, Alinia T, Sadeghi M, Mohammad-Shafiee G, et al. Adolescent perception on school environment and smoking behavior: analysis of Isfahan tobacco use prevention program. Int J Prev Med 2014; 5 Suppl 2:S139-45.

42. Alesci NL, Forster JL, Blaine T. Smoking visibility, perceived acceptability, and frequency in various locations among youth and adults. Prev Med 2003; 36:272-81.

43. Wakefield MA, Chaloupka FJ, Kaufman NJ, Orleans CT, Barker DC, Ruel EE. Effect of restrictions on smoking at home, at school, and in public places on teenage smoking: cross sectional study. BMJ 2000; 321:333-7. 


\section{Resumo}

O estudo tem como objetivos quantificar a importância global da escola na explicação da variância individual no uso de tabaco e testar a associação entre as características do ambiente escolar e o entorno e a experimentação e o uso atual de cigarros. Analisamos os dados de 102.072 adolescentes brasileiros entrevistados na Pesquisa Nacional de Saúde Escolar (PeNSE) de 2015. Foram utilizados modelos de regressão logística multinível para estimar a variância entre escolas e testar a associação entre variáveis escolares e o tabagismo. As características da escola foram a violência no entorno e a presença de professores e alunos fumando no ambiente escolar. As análises foram ajustadas para covariáveis individuais e estratificadas por sexo. Cerca de 12,5\% da variância individual no tabagismo pregresso ou atual foram explicados pela variação entre escolas, no sexo feminino (9,2\% no sexo masculino). As proporções foram ainda mais altas para o tabagismo atual (14,9\% no sexo feminino; $12,2 \%$ no sexo masculino) e para o uso atual de outros produtos de tabaco (27,7\% no sexo feminino; $17,8 \%$ no sexo masculino). Em geral, o uso de tabaco mostrou estar associado à existência de violência no entorno da escola, sendo mais frequente entre alunos cujas escolas relatavam que alunos e professores fumavam no ambiente escolar (para professores, apenas para o uso de outros produtos de tabaco, entre alunas). O uso de tabaco no ambiente escolar e a segurança no entorno da escola estão associados a alguns comportamentos relacionados ao tabaco entre adolescentes. Os achados reforçam a necessidade de considerar intervenções no ambiente escolar e no entorno para combater o tabagismo entre adolescentes

Tabaco; Fumar; Adolescente; Comportamentos de Risco à Saúde; Análise Multinível

\section{Resumen}

Este estudio tiene como objetivo cuantificar la importancia global de las escuelas a la hora de explicar la variancia individual del consumo de tabaco, así como probar la asociación entre las características del entorno de la escuela y sus inmediaciones con probar por primera vez y consumir cigarrillos habitualmente. Analizamos los datos de 102.072 brasileños adolescentes, entrevistados en la Encuesta Nacional de Salud Escolar (PeNSE) 2015. Se usaron modelos de regresión logística multinivel para estimar la variancia entre escuelas y para probar la asociación entre las variables de nivel escolar y consumo de tabaco. La violencia en las inmediaciones de la escuela y la presencia de profesores o estudiantes fumando en las instalaciones de la escuela fueron características del nivel escolar. Los análisis fueron ajustados por covariables individuales y estratificadas por género. Alrededor de un 12,5\% de la variancia individual entre quienes habian fumado se explicó mediante la variación interescolar entre chicas (9,2\% entre chicos). Las cifras fueron incluso superiores para los fumadores en la actualidad (14,9\% chicas; $12,2 \%$ chicos) y el consumo actual de otros productos derivados del tabaco (27,7\% chicas; $17,8 \%$ chicos). En general, el consumo de tabaco estuvo asociado con la existencia de violencia en las inmediaciones de las escuelas y fue superior entre estudiantes en cuyas escuelas se informó que estudiantes y profesores (profesores solo por el consumo de otros productos del tabaco entre chicas) fuman en dependencias escolares. El consumo de tabaco y la seguridad del vecindario donde estaba ubicada la escuela están asociados con algunos hábitos de consumo de tabaco entre adolescentes. Tales resultados refuerzan la necesidad de considerar efectivamente intervenciones en el entorno escolar $y$ en el vecindario para luchar contra el tabaquismo entre adolescentes

Tabaco; Fumar; Adolescente; Conductas de Riesgo para la Salud; Análisis Multinivel

Submitted on 22/Mar/2019

Final version resubmitted on 12/Jun/2019

Approved on 17/Jun/2019 